\title{
Seroprevalence of hepatitis B in pregnant women in Mexico
}

\author{
José Luis Vázquez-Martínez, MSc, , (1) María Ofelia Coreño-Juárez, MD, ${ }^{(2)}$ Luis Felipe Montaño-Estrada, PhD, ${ }^{(3)}$ \\ Michaël Attlan, Ing, ${ }^{(4)}$ Héctor Gómez-Dantés, MSc. (1)
}

\section{Vázquez-Martínez JL, Coreño-Juárez MO, Montaño-Estrada LF, Attlan M, Gómez-Dantés H. Seroprevalence of hepatitis B in pregnant women in Mexico. Salud Publica Mex 2003;45:165-170. \\ The English version of this paper is available too at: http://www.insp.mx/salud/index.html}

\begin{abstract}
Objective. To determine the seroprevalence of hepatitis B in pregnant women from several regions of Mexico, as well as the risk factors associated with its occurrence. Material and Methods. A cross-sectional study was conducted between May and August 2000. It included 9992 pregnant women attending the health services of the Mexican Institute of Social Security (Instituto Mexicano del Seguro Social-IMSS) in five cities: Tijuana, Ciudad Juarez, Acapulco, Cancun, and Mexico City (northeast and southeast regions). Results. The overall prevalence for confirmed cases was $1.65 \%$ (165/ 9 992). The prevalences for individual cities were as follows: Tijuana, I.27\%; Ciudad Juarez, I.46\%;Acapulco, 2.47\%; Cancun, $0.93 \%$; northeastern Mexico City, I.20\%, and southeastern Mexico City, 2.52\%. The risk factors found to be associated with $\mathrm{HBsAg}$ were: age, age at first sexual intercourse, city (Acapulco and southeastern Mexico City), and marital status (single or divorced). Conclusions. The prevalence of $\mathrm{HBsAg}$ in pregnant women (I.65\%) was greater than that reported in previous studies and showed geographical differences. This high prevalence suggests that a considerable amount of cases of hepatitis B occurs perinatally and through contact with carriers in the general population. Vaccination of newborns of high-risk pregnant women should be considered. The English version of this paper is available too at: http://www.insp.mx/salud/index.html
\end{abstract}

Key words: hepatitis B; prevalence; pregnancy; Mexico
Vázquez-Martínez JL, Coreño-Juárez MO, Montaño-Estrada LF, Attlan M, Gómez-Dantés H. Seroprevalencia de hepatitis B en mujeres embarazadas en México.

Salud Publica Mex 2003;45:165-170.

El texto completo en inglés de este artículo también está disponible en: http://www.insp.mx/salud/index.html

\section{Resumen}

Objetivo. Determinar la seroprevalencia de hepatitis B en mujeres embarazadas de varias regiones de México e investigar factores de riesgo asociados. Material y métodos. Durante el periodo de mayo-agosto del año 2000 se realizó un estudio transversal en 9992 mujeres embarazadas, con acceso a seguridad social (Instituto Mexicano del Seguro Social) en cinco ciudades de México:Tijuana, Ciudad Juárez, Acapulco, Cancún y Distrito Federal (zona noreste y sureste). Resultados. La prevalencia global para casos confirmados fue de $1.65 \%$ (165/9 992). Para las ciudades de estudio fue: $1.27 \%$ en Tijuana, I.46\% en Ciudad Juárez, $2.47 \%$ en Acapulco, $0.93 \%$ en Cancún, I. $2 \%$ en el noreste del Distrito Federal, y $2.52 \%$ en el sureste del Distrito Federal. Los factores de riesgo identificados fueron: edad, edad de inicio de vida sexual, ciudad (Acapulco y región sureste del Distrito Federal) y estado civil (solteras-divorciadas). Conclusiones. La prevalencia de antígeno de superficie del virus de la hepatitis $B(\mathrm{HBsAg}$, por sus siglas en inglés) en embarazadas (1.65\%) es mayor a la reportada en investigaciones previas y muestra diferencias geográficas. Esta prevalencia elevada indica un número considerable de casos de hepatitis $\mathrm{B}$ ocasionados por vía perinatal y de portadores en nuestra población. Se debe considerar la vacunación en recién nacidos de mujeres embarazadas con alto riesgo. El texto completo en inglés de este artículo también está disponible en: http://www.insp.mx/salud/index.html

Palabras clave: hepatitis B; prevalencia; embarazo; México

(I) División Técnica de Información y Estadísticas en Salud. Instituto Mexicano del Seguro Social (IMSS), México, DF, México.

(2) Coordinación de Salud Comunitaria, IMSS, México, DF, México.

(3) Departamento de Biología Celular, Instituto Nacional de Cardiología Ignacio Chávez, México, DF, México.

(4) Aventis Pasteur México. México, DF, México.

Received on: June 5, 2002 - Accepted on: January 15, 2003

Address reprint requests to: Dr. José Luis Vázquez. Durango 289 60. piso, colonia Roma, 06700 México, DF, México. E-mail: cinth@prodigy.net.mx 
I nfection with the hepatitis B virus (HBV) is considered a public health problem worldwide. According to World Health Organization (WHO) estimates, there were 400 million carriers of the infection in 2000. Every year, approximately one million people die because of the association between HBV and the development of chronic clinical forms such as active chronic hepatitis, cirrhosis, and hepatic carcinoma. ${ }^{1-3}$

Seroepidemiologic studies carried out in several Latin American countries revealed a wide range of prevalences for antibodies against the core antigen (Anti-HBc), ranging from $0.6 \%$ in Chile to $21.4 \%$ in the Dominican Republic. The seroprevalence in Mexico was $1.4 \%$, with similar frequencies by gender: $1.3 \%$ among males and $1.5 \%$ among females. In Brazil, the prevalence ranged from $1.2 \%$ in Fortaleza to $21 \%$ in the area of Manaus, with a greater risk for males (OR 1.32). This study also demonstrated a $0.1 \%$ seroprevalence for the hepatitis B virus surface antigen (HBsAg) in Mexico, as compared with $1.9 \%$ in the Dominican Republic. ${ }^{4}$ However, high-prevalence areas have been identified in the American Continent, particularly in the Amazon region, where the carrier prevalence in certain communities is as high as $15 \%$ and previous infection up to $84 \% .^{5}$ In the United States of America, the incidence of $\mathrm{HBV}$ infection dropped $70 \%$, especially among children, health workers, and other groups exposed to vaccination campaigns during the past decade. ${ }^{6}$ The National Health and Nutrition Examination Survey (NHANES III) study showed a $0.42 \%$ seroprevalence for HBsAg in the population between 6 and 74 years of age. ${ }^{7}$

Transmission mechanisms of infection include vertical transmission from mother to child, which is associated with a greater probability of generating carriers and consequently of maintaining the infection in the population. Some authors point out that the proportion of carriers among children born to mothers with a history of HBsAg seropositivity can range between $70 \%$ and $90 \%$. ${ }^{1,8}$ Thus, inclusion of the vaccine against $\mathrm{HBV}$ in the universal vaccination program has been recommended among the strategies for controlling the infection..$^{9-11}$ In the United States of America and some European countries, prevention of perinatal transmission by screening for HBsAg in all pregnant women with a history of hepatitis B has also been recommended. These screening programs would allow the timely administration of a vaccine in newborns born to seropositive mothers. ${ }^{8,12-14}$

Studies that describe the magnitude of the problem in Mexico are limited. In 1993, Alvarez-Muñoz et al, conducted a survey on hepatitis B seroprevalence in pregnant women seen in two medical settings: a primary health care unit and a hospital specialized in perinatal care. The seroprevalence for any of the seromarkers (Anti-HBc; Anti-HBs; HBsAg or Anti-HBe) was $1.67 \%$ in the primary health care unit and $2.24 \%$ in the highly specialized hospital. Prevalence of HBsAg was $0.02 \%(1 / 5130)$ in pregnant women without complications, and $0.09 \%(1 / 1123)$ in women with highrisk pregnancies. ${ }^{15}$ A later study conducted during 1995 in 1500 high-risk pregnancies at the National Institute of Perinatology in Mexico City, showed a $0.26 \%$ prevalence for $\mathrm{HBsAg} .{ }^{16}$

In Mexico, morbidity data for hepatitis B infection show that it is decreasing, a trend that is supported by seroprevalence studies, seropositivity in blood banks, and epidemiologic surveillance systems operating in this country. However, most cases are of a prevalent type and associated with different transmission mechanisms, which makes it impossible to define the sources of infection and frequency of pregnant women who are carriers in the study population. The objective of the present study is to determine the seroprevalence of hepatitis B infection in pregnant women who were beneficiaries of the Mexican Institute of Social Security (Instituto Mexicano del Seguro Social-IMSS) in five cities in Mexico and to identify associated risk factors.

\section{Material and Methods}

A cross-sectional study was conducted from March to August 2000. The estimated sample size was 10000 of the 800000 pregnant women who are attended each year in the IMSS. The expected HBsAg prevalence was $0.2 \%$, and the non-response was $30 \%$. Women were recruited in the study after upon entering IMSS hospital prenatal care areas in the following cities: Tijuana, Ciudad Juarez, Acapulco, Cancun, and the eastern part of Mexico City, which was divided into two areas: the northeast and southeast administrative IMSS areas.

Seropositivity to $\mathrm{HBsAg}$, $\mathrm{HBeAg}$, and its corresponding antibody (Anti-HBe) was determined using serum collected from 5-ml blood samples during the routine prenatal examination performed for all pregnant women. The blood was centrifuged for $10 \mathrm{minu}-$ tes at $6000 \mathrm{rpm}$ and refrigerated for a maximum of 12 hours; once the serum was separated, it was stored in two 2-ml cryo-tubes and kept in a freezer at $-20^{\circ} \mathrm{C}$. The samples were not thawed until the moment the assay was performed. The presence of the hepatitis B virus surface antigen was determined with the product Monolisa Ag-HBs Plus, a commercial assay made by Sanofi Diagnostics Pasteur (France), which uses three monoclonal antibodies selected for their ability to bind 
with the different subtypes of HBsAg recognized by the World Health Organization. The serum samples were brought to room temperature and $100 \mu \mathrm{l}$ of serum were applied in duplicate per well. Each plate of 96 wells contained 4 wells with the negative control serum and 2 wells with the positive control serum included in the kit. Once the plate was filled with the sera and the controls, $50 \mu \mathrm{l}$ of conjugate solution (tris- $\mathrm{HCl} / \mathrm{BSA} /$ Tween-20) were applied, and two different anti-HBsAg monoclonal antibodies peroxidase marked by well; the plate was covered with adhesive film, and incubated for 2 hours at $40{ }^{\circ} \mathrm{C}$ in a water bath. When incubation was completed, the adhesive film was removed and the plate thoroughly cleaned with the washing solution (Tris/ $\mathrm{NaCl}, \mathrm{pH} 7.4$ ) included in the kit. After this, $100 \mu$ l of enzymatic developing solution were added to each well and the plate was incubated for 30 minutes at room temperature in a dark room. After incubation, $100 \mu \mathrm{l}$ of stop solution were added and 20 minutes later the plate was read at a wavelength of $450 / 620 \mathrm{~nm}$ in an enzyme-linked immunosorbent assay (ELISA) EL 311 reader (Bio-Tek Instruments). The cutoff value was determined using the Bio-Tek KC4 program, according to the following formula: the average reading of the 4 negative controls plus 0.040; any values above this figure were considered positive. The level of detection of the assay is $0.10 \mathrm{ng} / \mathrm{ml}$ of $\mathrm{HBsAg}$, and its specificity is $99.98 \%$. Samples whose reading was $10 \%$ or less below the cutoff value were considered indeterminate and the sample was assayed again in duplicate. If the result was repeated, these samples were classified as indeterminate.

The qualitative determination of $\mathrm{HBeAg}$ was only performed on HBsAg-positive samples, using a commercial assay of ELISA in plates (Monolisa HBeAg) made by the same manufacturer of the HBsAg assay. The samples were analyzed at the Clinical Immunology Laboratory of the National Institute of Cardiology "Ignacio Chavez" in Mexico City.

Using a questionnaire, the following data were collected from each participant: personal identification data, age, gynecologic and obstetric variables, transmission mechanisms, and potential risk factors. Women who were found to be HBsAg positive continued until the end of their pregnancy and an anti-hepatitis $B$ vaccine was administered to newborns within 24 hours after birth.

Data analysis included central frequency and dispersion measures for continuous variables and percentages for categorical variables. For the overall seroprevalence and prevalence in individual cities, 95\% confidence intervals were obtained for each estimate.
Indeterminate $\mathrm{HBsAg}$ results were incorporated into the global and individual cities' prevalence rates. Risk factors were assessed using odds ratios with $95 \%$ confidence intervals $(95 \% \mathrm{CI})$. Adjustment of covariates and possible confounding variables was done using multivariate logistic regression analysis. Statistical analysis was performed using the STATA version 6.0 statistical software (Stata Corp. College Station, TX).

\section{Results}

The total number of women included in the study was 9 992; 1500 women were selected per city with the exception of Mexico City, where 3981 women were interviewed. Only 38 women were excluded due to the unavailability of seromarkers. The average age of women was 26 years (range, 14 to 46 ), and the average age at first sexual intercourse was 19 years (range, 11 to 36). According to their marital status, married women accounted for $75 \%$ of the sample; $6.9 \%$ were single or divorced, and $18.2 \%$ were living in common law. Widows were the least represented $(0.05 \%)$. The educational status of the population was high, since $78 \%$ of women had more than elementary education. The gestational period ranged from 8 to 35 weeks, with an average of 22 weeks. The median value for the number of previous pregnancies was 2 and only $11.6 \%$ of the women were in their first pregnancy. A history of hepatitis $B$ vaccination was obtained in $6.4 \%$; a previous blood transfusion was reported in $4 \%$; $93 \%$ reported only one sexual partner in the previous year; $2 \%$ referred a sexually transmitted disease; $4 \%$ reported piercing, tattoos, or use of acupuncture in the past; and only $8 \%$ reported signs and symptoms supporting hepatitis infection (Table I).

The overall prevalence for the surface antigen was without the indeterminate results, $1 \%$, and for individual cities fluctuated between 0.60 (North-Eastern region of Mexico City) and 1.67\% (Southeastern region of Mexico City). The city of Acapulco shows the prevalence of $1.53 \%$. Table II showed a prevalence for $\mathrm{HBsAg}$, including the indeterminate results (66), and their distribution per city. The prevalence increased from 1 to $1.65 \%$, reaching a level of $2.5 \%$ in the South-Eastern region of Mexico City and in Acapulco.

HBeAg detection was performed only on positive samples and demonstrated active viral replication with a higher risk of perinatal transmission. The overall prevalence of antigen e (HBeAg) was $2 \%$ but increased to $3 \%$ and $8 \%$ in north-eastern and south-eastern Mexico City, respectively. Detection of corresponding antibody to $\mathrm{HBeAg}$, on the other hand, demonstrates an immune response that may decrease the risk of trans- 
Table I

Frequency of CHARACTERISTICS OF the GROUP of PREgnant Women IN THE Study. MeXico, 2000

\begin{tabular}{|c|c|c|c|c|c|}
\hline Characteristics & $N$ & $\%$ & Cases & Non cases & $p$ \\
\hline \multicolumn{6}{|l|}{ Age (years) } \\
\hline $14-22$ & 2703 & 27.3 & 17 & 2686 & \\
\hline $23-28$ & 4021 & 40.7 & 37 & 3984 & \\
\hline $29-46$ & 3170 & 32.0 & 45 & 3170 & 0.008 \\
\hline \multicolumn{6}{|l|}{ Marital status } \\
\hline Married & 7403 & 74.9 & 71 & 7332 & \\
\hline Unmarried-divorced & 679 & 6.9 & II & 668 & \\
\hline Common law & 1807 & 18.2 & 17 & 1790 & 0.244 \\
\hline \multicolumn{6}{|l|}{ Education } \\
\hline Elementary school (primary) & 2202 & 22.2 & 16 & 2186 & \\
\hline Junior high (secondary) & 3583 & 36.1 & 29 & 3554 & \\
\hline High school & 3271 & 32.9 & 42 & 3224 & \\
\hline Master's degree & 872 & 8.8 & 12 & 860 & 0.075 \\
\hline \multicolumn{6}{|l|}{ Age at first sexual intercourse } \\
\hline $11-16$ & 1921 & 19.4 & 10 & 1911 & \\
\hline $17-24$ & 6962 & 70.4 & 66 & 6896 & \\
\hline $25-36$ & 1002 & 10.2 & 23 & 979 & 0.001 \\
\hline
\end{tabular}

No. of previous pregnancies

\begin{tabular}{llllll}
0 & 1110 & 11.6 & 12 & 1098 & \\
\hline 1 & 3869 & 40.3 & 38 & $383 \mid$ & \\
\hline 2 & 2717 & 28.3 & 23 & 2694 & \\
\hline $3 y+$ & 1907 & 19.8 & 21 & 1886 & 0.824
\end{tabular}

History of Anti hepatitis B vaccination

\begin{tabular}{lrrrrr} 
Present & 637 & 6.4 & 6 & 631 & \\
\hline Absent & 9280 & 93.6 & 93 & 9187 & 0.882 \\
$\begin{array}{l}\text { History of blood transfusion } \\
\text { Present }\end{array}$ & 390 & 3.9 & 4 & 386 & \\
\hline Absent & 9527 & 96.1 & 95 & 9432 & 0.956 \\
$\begin{array}{l}\text { History of surgery } \\
\text { Present }\end{array}$ & 2942 & 29.7 & 34 & 2908 & \\
\hline Absent & 6975 & 70.3 & 65 & 6910 & 0.306 \\
$\begin{array}{l}\text { Paid blood donor } \\
\text { Present }\end{array}$ & 7 & 0.07 & 0 & 7 & \\
\hline Absent & 9909 & 99.93 & 99 & 9810 & 0.790
\end{tabular}

Number of sexual partners

\begin{tabular}{lrrrrr}
1 & 9179 & 93.0 & 92 & 9087 & \\
\hline 2 & 582 & 5.9 & 7 & 575 & \\
\hline $3 y+$ & 109 & 1.1 & 0 & 109 & 0.512
\end{tabular}

History of venereal disease

\begin{tabular}{lrrrrr} 
Present & 187 & 1.9 & 2 & 185 & \\
\hline Absent & 9730 & 98.1 & 97 & 9633 & 0.921
\end{tabular}

Acupuncture

\begin{tabular}{lrrrrr}
$\begin{array}{c}\text { Acupuncture } \\
\text { Present }\end{array}$ & 401 & 4.0 & 8 & 393 & \\
\hline Absent & 9516 & 96.0 & 91 & 9425 & 0.040
\end{tabular}

Tattoos

\begin{tabular}{lrrrrr} 
Present & 428 & 4.3 & 2 & 426 & \\
\hline Absent & 9488 & 95.7 & 97 & 9391 & 0.259
\end{tabular}

Presence of some sign or symptom

(pain in right hypochondrium,

jaundice, bilirubinuria, acholia)

\begin{tabular}{lrrrrr} 
Present & 799 & 8.0 & 13 & 786 & \\
\hline Absent & 9118 & 92.0 & 86 & 9032 & 0.062 \\
$\begin{array}{l}\text { History of dental therapy } \\
\text { Present }\end{array}$ & & & & & \\
\hline Absent & 3511 & 35.4 & 37 & 3474 & \\
\hline & 6417 & 64.6 & 62 & 6355 & 0.674
\end{tabular}

mission at birth. The prevalence of antibodies against antigen e (Anti-HBe) was 9.1\% in northeastern Mexico City; $41.7 \%$ in southeastern Mexico City, $17.4 \%$ in Acapulco, and $10 \%$ in Cancun (Table III).

Table IV shows the risk factors associated with infection. The risk of infection increased with age (OR 1.04, 95\%CI 1.003-1.08). Marital status also influenced the risk, especially in those single or divorced (OR 1.92, 95\% CI 1.00-3.67), while age at first sexual intercourse (17-24; 25-36) was also associated (OR 1.64, 95\%CI 0.83 3.23 to OR 3.24, 95\%CI 1.44-7.28). Cities had the highest risks and were most important in southeastern Mexico City (OR 3.12, 95\%CI 1.59-6.08) and Acapulco (OR 3.20, 95\%CI 1.57-6.51).

Table II

Prevalence of HBsAg in pregnant women in five Mexican Cities, $* 2000$

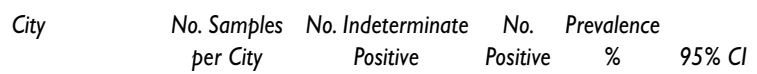

\begin{tabular}{lrrrrr} 
Mexico City $2^{\ddagger}$ & 2000 & 12 & 12 & 1.20 & $0.72-1.68$ \\
\hline Mexico City $4^{\S}$ & $198 \mathrm{I}$ & 17 & 33 & 2.52 & $1.83-3.22$ \\
\hline Ciudad Juarez & 1510 & 12 & 10 & 1.46 & $0.85-2.06$ \\
\hline Tijuana & 1500 & 8 & 11 & 1.27 & $0.70-1.83$ \\
\hline Acapulco & $150 \mathrm{I}$ & 14 & 23 & 2.47 & $1.68-3.25$ \\
\hline Cancun & 1500 & 4 & 10 & 0.93 & $0.45-1.42$ \\
\hline Total & 9992 & 66 & 99 & 1.65 & $1.40-1.90$
\end{tabular}

* Includes indeterminate results

₹ Northeast Region of Mexico City

$\S$ Southeast Region of Mexico City

Table II

Frequency of antigen e (HBeAg) and antibodies against antigen e (Anti-Be). Mexico, 2000

$\begin{array}{ccccc}\text { No. Positives } & \begin{array}{c}\text { Antigen e } \\ \text { City }\end{array} & \begin{array}{c}\text { Antibodies against } \\ \text { HBsAg }\end{array} & \begin{array}{c}\text { (HBeAg) } \\ \text { antigen e (Anti-HBe) }\end{array} \\ & \text { per city* } & \text { No. Positive } \% & & \text { No. Positive \% }\end{array}$

\begin{tabular}{lccccc} 
Mexico City $2^{\ddagger}$ & 12 & $\mathrm{I}$ & 8.33 & 5 & 41.7 \\
\hline Mexico City $4^{\S}$ & 33 & $\mathrm{I}$ & 3.03 & 3 & 9.1 \\
\hline Ciudad Juarez & 10 & 0 & 0.00 & 0 & 0 \\
\hline Tijuana & 11 & 0 & 0.00 & 0 & 0 \\
\hline Acapulco & 23 & 0 & 0.00 & 4 & 17.4 \\
\hline Cancun & 10 & 0 & 0.00 & 1 & 10.0 \\
\hline Total & 99 & 2 & 2.02 & 13 & 13.1
\end{tabular}

* Only positives

\# Southeast Region of Mexico City

$\S$ Northeast Region of Mexico City 
Table IV

RISK FACTORS FOR SEROPOSITIVITY TO SURFACE Antigen in PRegnant Women. MeXico, 2000

$\begin{array}{cccc}\text { Risk factor } & \text { Odds ratio } & p & 95 \% \mathrm{Cl} \\ \text { Age (years) } & 1.04 & 0.034 & 1.003-1.08\end{array}$

Age at first sexual intercourse

\begin{tabular}{llll}
$11-16$ & 1.00 & & \\
\hline $17-24$ & 1.64 & 0.150 & $0.835-3.23$ \\
\hline $25-36$ & 3.24 & 0.004 & $1.443-7.28$
\end{tabular}

City

\begin{tabular}{lllr} 
Northeast Mexico City & 1.00 & & \\
\hline Southeast Mexico City & 3.12 & 0.001 & $1.599-6.08$ \\
\hline Ciudad Juarez & 1.34 & 0.508 & $0.56-3.16$ \\
\hline Tijuana & 1.60 & 0.267 & $0.69-3.68$ \\
\hline Acapulco & 3.20 & 0.001 & $1.57-6.51$ \\
\hline Cancun & 1.51 & 0.348 & $0.63-3.55$
\end{tabular}

Marital Status

\begin{tabular}{llrr} 
Married & 1.00 & & \\
\hline Single-divorced & 1.92 & 0.049 & $1.003-3.67$ \\
\hline Common law & 1.28 & 0.375 & $0.74-2.21$
\end{tabular}

Adjusted for age

No. of observations: 9 839; 153 missing values

\section{Discussion}

The prevalence of hepatitis B infection in Mexico is not clearly understood and has not been adequately studied. HBsAg prevalence in Mexico during the period 1975 to 1985 was estimated to be about $1 \%(0.33-1.6 \%),{ }^{17}$ and a national serosurvey confirmed that the previous $\mathrm{HBV}$ infection prevalence rate was $1.4 \%$ for Anti-HBc, and $0.1 \%$ for $\mathrm{HBsAg}$. ${ }^{4}$ Two other studies were conducted during the mid-90's at the National Institute of Perinatology (Instituto Nacional de Perinatología). Healthy pregnant women and women with perinatal risk showed lower estimates; $0.02 \%$ (HBsAg) and 0.09$0.26 \%$ (HBsAg), respectively. ${ }^{15,16}$ Data from blood banks in the country from 1997 to 2000, showed a prevalence around $0.5 \%(\mathrm{HBsAg}){ }_{1}^{18}$ while the seroprevalence of HBsAg in voluntary donors at two private hospitals in Mexico City was $0.11 \%$ and $0.32 \% .{ }^{19,20}$ It is possible that the different prevalences mentioned are due to geographic variations and different sample populations. As we pointed out in our study, the geographical differences were very clear. Our study was carried out in five cities in Mexico and included cities in the northern, central, and southern parts of the country, unlike the studies of Alvarez-Muñoz et $\mathrm{al}_{1}^{15}$ who obtained the population sample from only 10 medical units in Mexico City; the other study was conducted by Ortiz-Garcia et $a l_{1}^{16}$ in patients from a highly specialized hospital.

Potential limitations of our study are those inherent to any cross-sectional design. The main one is the impossibility to establish causal associations. Nevertheless, among its strengths is the generation of hypothesis that should be tested in further research. A suggestion is made to assess migration and tourism as important risk factors. Our results agree with the seroprevalence reported by Landa ${ }^{21}$ in the seventies (who found a prevalence of $0.35 \%$ in the southern Pacific area; $0.32 \%$ in the Southern Central area; $0.25 \%$ in the Peninsula de Yucatan; $0.10 \%$ in the northern region, and $0.25 \%$ nationwide) and confirms the representative nature of the cities as places with high prevalence rates of HBsAg. Differences within cities were also detected in Landa's study, with a $6.5 \%$ overall prevalence of previous infection (anti-HBs) in Mexico City, but $7.5 \%$ for Ciudad Netzahualcoyotl, $7.35 \%$ for Tlatelolco and Tepito, and 3.91\% in the San Angel neighborhood of the city. ${ }^{21}$

Infection risks naturally increase with age and these results are consistent with those of other authors. ${ }^{4,15,22}$ Other studies also show that an early age of sexual intercourse is a risk factor for acquiring the infection. ${ }^{7}$ In this study, a higher risk was observed at older ages, a situation that could be related to age of the sexual partner, who is usually the main source of infection for women. In this sense the most affected group was that from 25 to 44 years of age (1.37 per 100000 ) and that from 45 to 64 (1.77 per 100000$)$, figures that are similar to those observed in all social security beneficiaries for 1999, as well as in the population of Latin America. ${ }^{23}$

Our results also confirmed that a relationship exists between the presence of infection and women's marital status, especially in the case of divorcees compared to married women. ${ }^{7}$ Although other risk factors, in particular those associated with percutaneous transmission, were not identified by our study, its presence in pregnant women should be an indication to screen for HBsAg. Since most women who were HBsAg positive were negative to antibodies against antigen e (AntiHBe), we presumed that $82 \%$ of this group may be considered carriers of the infection. ${ }^{24}$

The results herein presented still argue in favor of a low endemicity of HBV infection in Mexico, which means that the infection remains mainly sexually transmitted. Nevertheless, a striking finding is that the pre- 
valence in our study resembled that observed in the Dominican Republic (1.9\%). In our study, we observed a high prevalence of HBsAg in pregnant women, with a potential increase in the number of new cases caused perinatally and therefore a large increase in HBV carriers. In addition, we should be aware that "occult HBV" has been described, especially in patients that are in a window period, and they should be considered within the infection frequency in the population studied..$^{25}$ Some potential problems with the prevalences detected in the study could be associated with a high rate of false positives. This could only be possible if the sensitivity and specificity of the test are low, which is not the case, since the test used in the study -Monolisa, from Sanofi-Pasteur- is used as a standard in validation tests in other countries because of its ability to detect levels as low as $0.12 \mathrm{ng} / \mathrm{ml}$ of $\mathrm{HBsAg}$, with high sensitivity and specificity. ${ }^{26}$ However, it must be acknowledged that the soundness of our results would have improved if we had been able to perform the confirmation of ELISA positive results by applying the HBsAg neutralization test.

Considering the results of this study, the possibility of implementing preventive measures should be assessed, in particular those established by the $\mathrm{WHO}$ and other international organizations. Blood banks are the only source of information besides information obtained through specific research. Data obtained from blood banks should guide the selection of areas with a high seroprevalence, where screening of pregnant women should be performed. Evaluation of introducing anti-HB vaccine at birth into the vaccination program should also be considered. ${ }^{27}$

\section{References}

I.World Health Organization. Hepatitis B vaccine: Making global progress. Epi Update 31. 1996. Ginebra:WHO, 1996.

2. Lee WM. Hepatitis BVirus Infection. N Engl J Med 1997;337: 1733-1745.

3. Beasley RP, Hwang LY, Lin CC, Chien CS. Hepatocellular carcinoma and hepatitis B virus. A prospective study of 22707 men in Taiwan. Lancet 1981;2:1 129-1 I33.

4. Thêmis RS, Fonseca JC, Rivera L, Fay OH, Tapia R, Santos Jl et al. Hepatitis B seroprevalence in Latin America. Rev Panam Salud Publica 1999;6(6): 378-383.

5. Soares MCP, Menezes RC, Martins SJ, Bensabath G. Epidemiologia dos vírus das hepatites $B, C$, e D na tribu indígena Parakana Amazônia Oriental Brasileira. Bol Oficina Sanit Panam 1994; I 17:124-I34.

6. Lok AS, Heathcote JE, Hoofnagle JH. Management of Hepatitis B: 2000. Gastroenterology 2001;120:1828-1853.

7. McQuillan G, Coleman PJ, Kruszon-Moran D, Moyer LA, Moyer LA, Lambert SB et al. Prevalence of Hepatitis BVirus Infection in the United
States: The National Health and Nutrition Examination Surveys, 1976 Through 1994. Am J Public Health 1999;89:14-18.

8. Sáenz-González MC. Hepatitis B, Hepatitis C, Hepatitis D y Hepatitis G, Enfermedades Transmisibles-Hepatitis B: Medicina Preventiva y Salud Pública. Barcelona, España: Ed. Mason, 2001:540-548.

9. Halsey NA. Discussion of Immunization Practices Advisory Committee/American Academy of Pediatrics. Recommendations for universal infant hepatitis B vaccination. Pediatr Infect Dis J 1993 May; I2(5):446-449.

IO.Van Damme P, Kane M, Meheus A. Integration of hepatitis B vaccination in national immunization programmes. BMJ 1997;314: 1033-1036.

II. World Health Organization. Expanded Programme on Immunization Global Advisory Group. Weekly Epidemiol Record 1992;3: I I-16. 12. Centers For Disease Control. Hepatitis B Virus. A comprehensive strategy for eliminating transmission in the United States through universal childhood vaccination. MMWR 199|;40(RR-13): I-25.

13. Centers For Disease Control. Maternal hepatitis B screening practices - California, Connecticut, Kansas, and United States, 19921993. MMWR Morb MortalWkly Rep 1994;43:3 I I- 320.

14. Mortimer PP, Miller E. Commentary:Antenatal screening and targeting should be sufficient in some countries. BMJ 1997;314: 1036-1037.

15. Alvarez-Muñoz MT, Vázquez-Rosales JG, Torres-López J, ArredondoGarcía JL, Bustamante-Calvillo ME, Del Rey-Pineda G et al. Infection of pregnant women with hepatitis $B$ and $C$ viruses and risk for vertical transmission. Arch Med Res 1997;28(3):415-419.

16. Ortiz-lbarra FJ, Figueroa-Damián R, Lara-Sánchez J, ArredondoGarcía JL, Ahued-Ahued JR. Seroprevalence of hepatitis A, B, C and D infection in pregnant women. Salud Publica Mex 1996; 38:317-322. 17. Hadler SC, Fay OH, Pinheiro F, Maynard JE. La hepatitis en las Américas. Informe del Grupo Colaborador de la OPS. Bol Oficina Sanit Panam 1987;103(3):185-209.

18. Organización Panamericana de la Salud. Medicina transfusional en América Latina 1994-2000. Washington, DC: OPS, 2001;OPS/HSE-LAB/ 04.2001.

19. Méndez-Sanchez N, Baptista-González H, Sánchez-Gómez RH, Bordes-Aznar J, Uribe-Esquivel M. Prevalence of type $C$ and $B$ hepatitis in blood donors at a third level hospital of Mexico City. Salud Publica Mex 1999;41:475-478.

20. Souto-Meiriño CA, Simón-Domínguez J, Pulido-Priego MA, Hernández-Pérez A, García-Hernández IC, Del Río-Chiriboga CA. Prevalence of $A, B$ and $C$ hepatitis markers in a Mexico City hospital. Salud Publica Mex 1994; 36:257-262.

21. Landa L. Seroepidemiología de la hepatitis B. Gac Med Mex 1976; I II(2): I08-II3.

22. Al-Shamahy H. Prevalence of hepatitis B surface antigen and risk factors of HVB infection in a sample of healthy mothers and their infants in Sana'A, Yemen. Ann Saudi Med 2000;20(5):464-467.

23. Instituto Mexicano del Seguro Social. Boletín Epidemiológico Anual 1999, México, DF: IMSS, 1999.

24. World Health Organization. WHO-recommended standards for surveillance of selected vaccine-preventable diseases. Ginebra:WHO, 1998.

25. Cacciola I, Pollicino T, Squadrito G, Cerenzia G, Orlando ME, Raimondo ME. Occult hepatitis B virus infection in patients with chronic hepatitis C liver disease. N Engl J Med 1999;34I:I22-126.

26. Suslov AP, Kuzin SN, Sadikova NV, Elgort DA, Feldsherova AA, Nikolaev VL et al. Performance of ELISA HBsAg test kits with use of the different types of panels containing $\mathrm{HBsAg}$. Russian J Immunol 2000;5(2):218-226.

27. Mast EE, Alter MJ, Margolis HS. Strategies to prevent and control hepatitis $B$ and $C$ virus infections: $A$ global perspective. Vaccine 1999; 17: 1730-1733. 